\title{
Namibian literary archives: new beginnings and a possible African model
}

Book or Report Section

Published Version

Creative Commons: Attribution-Noncommercial-No Derivative Works 4.0

Open Access

Kauaria, V. V. and Sutton, D. C. (2018) Namibian literary archives: new beginnings and a possible African model. In: Sutton, D. C. and Livingstone, A. (eds.) The Future of Literary Archives: Diasporic and Dispersed Collections at Risk. ARC, pp. 65-74. ISBN 9781942401575 Available at https://centaur.reading.ac.uk/78021/

It is advisable to refer to the publisher's version if you intend to cite from the work. See Guidance on citing.

Publisher: ARC

All outputs in CentAUR are protected by Intellectual Property Rights law, including copyright law. Copyright and IPR is retained by the creators or other copyright holders. Terms and conditions for use of this material are defined in the End User Agreement.

\section{www.reading.ac.uk/centaur}

\section{CentAUR}

Central Archive at the University of Reading 
Reading's research outputs online 
THE FUTURE OF LITERARY ARCHIVES 


\section{COLLECTION DEVELOPMENT, CULTURAL HERITAGE, AND DIGITAL HUMANITIES}

This series publishes both monographs and edited thematic collections in the broad areas of cultural heritage, digital humanities, collecting and collections, public history, and allied areas of applied humanities. In the spirit of our mission to take a stand for the humanities, this series illustrates humanities research keeping pace with technological innovation, globalization, and democratization. We value a variety of established, new, and diverse voices and topics in humanities research, and this series provides a platform for publishing the results of cutting-edge projects within these fields.

The aim is to illustrate the impact of humanities research and in particular reflect the exciting new networks developing between researchers and the cultural sector, including archives, libraries and museums, media and the arts, cultural memory and heritage institutions, festivals and tourism, and public history.

\section{Acquisitions Editor}

Danièle Cybulskie

\section{Evaluation and Peer Review}

The press has every proposal independently evaluated by expert reviews before any formal commitment is made by the press to the author. Further, all submitted manuscripts are subject to peer review by an expert chosen by the press. 


\title{
THE FUTURE OF LITERARY ARCHIVES: DIASPORIC AND DISPERSED COLLECTIONS AT RISK
}

\author{
Edited by
}

DAVID C. SUTTON with ANN LIVINGSTONE 


\section{British Library Cataloguing in Publication Data}

A catalogue record for this book is available from the British Library

\section{(C) 2018, Arc Humanities Press, Leeds}

cc) (i) $\fallingdotseq$ (5) This work is licensed under a Creative Commons Attribution-

NonCommercial- NoDerivatives 4.0 International Licence.

The author asserts their moral right to be identified as the author of their part of this work.

Permission to use brief excerpts from this work in scholarly and educational works is hereby granted provided that the source is acknowledged. Any use of material in this work that is an exception or limitation covered by Article 5 of the European Union's Copyright Directive (2001/29/EC) or would be determined to be "fair use" under Section 107 of the U.S. Copyright Act September 2010 Page 2 or that satisfies the conditions specified in Section 108 of the U.S. Copyright Act (17 USC §108, as revised by P.L. 94-553) does not require the Publisher's permission.

ISBN: 9781942401575

e-ISBN: 9781942401582

\section{https://arc-humanities.org}

Printed and bound by CPI Group (UK) Ltd, Croydon, CR0 4YY 
Chapter 6

\title{
NAMIBIAN LITERARY ARCHIVES: NEW BEGINNINGS AND A POSSIBLE AFRICAN MODEL
}

\author{
VENO V. KAUARIA AND DAVID C. SUTTON
}

The National Archives of Namibia signed up with enthusiasm to the Section for Archives of Literature and Art (SLA) of the International Council on Archives in 2010 and then to the emerging Diasporic Literary Archives Network in 2011-on behalf of a country with a strong literary culture but no established practice of collecting literary manuscripts, nor the correspondence and personal papers of literary authors.

Namibia was asked to play the role of the apprentice within the Network and has played that role fully and creatively-moving towards a position where by 2020 it aims to be a model in southern and eastern Africa for the collection and appreciation of literary and cultural papers.

Namibia accepted one of the principal messages of the Diasporic Literary Archives Network, which was that literary papers themselves could serve as a key part of the cultural heritage of countries which had achieved their independence within current lifetimes, and could provide a source of national pride, diversity, and identity.

Diversity had always been a prominent feature of cultural archives in Namibia, adding great variety to the archival collections while also sometimes deriving from controversial and painful aspects of national history. There had always been South African authors who lived in Namibia and Namibian authors who lived in South Africa, for example. There were also archival fonds reflecting the colonial past of Namibia, and the successive regimes of Germany, Britain, and South Africa. For the documentation of colonial rule and occupation, the papers of the rulers survived more extensively than papers concerning resistance and the fight for freedom. This is no doubt a general truth found by archivists in newly independent countries, especially when independence has followed wars of liberation. As a result, in Namibia, papers of cultural interest (although not specifically literary) in the German and Afrikaans languages had been collected, as well as in English and in several Namibian languages. Historical literature and diaries of historical interest, in particular, had found their way into the archives, and the letter-journals of the Nama 
leader Hendrik Witbooi (died 1905), owned by the National Archives of Namibia, had been included on the UNESCO Memory of the World Register as long ago as 2004. This meant that the idea of acquisition of personal papers presented no problem of principle in respect of collecting policies. What was new in the work which began around 2012 was the interest in Namibian authors whose work belonged to the fields of literature and the arts.

Presentations on progress in Namibian literary archives were given at most of the workshops of the Diasporic Literary Archives Network, and the Network members were entertained by the metaphor of Namibia as its baby, first learning to crawl and then to walk and to run. Some creative and distinctively Namibian solutions were identified and discussed fairly early in the process.

For example, the combination of the National Library and Archives of Namibia into a single service made possible a simple but effective way of communicating with living authors. As a new literary work was deposited in the National Library of Namibia, under a copyright deposit scheme based on a British model and, ultimately, on the Imperial Copyright Act of 1911, the National Archives of Namibia was able to write to the author with an enquiry and an expression of interest relating to the manuscripts and working notes which lay behind the book.

Noting the work that had been done in other countries in respect of direct discussion and negotiation with living literary authors and (more discreetly and delicately) with the families of the recently dead, in 2014 the National Library and Archives of Namibia reported on discussions and negotiations about their archives which had begun with key figures in Namibian literature, notably Mvula ya Nangolo and Frederick Philander. These discussions led to the early deposit of papers and disks relating to Philander's literary work.

Between 2012 and 2014, thus, the Namibian archivists moved from being apprentice literary learners to being archival literary activists.

In 2015 a series of workshops organized in Windhoek jointly by the National Archives of Namibia, the National Library of Namibia, and the Diasporic Literary Archives Network, with support from the Thomas Fisher Rare Book Library at the University of Toronto, studied many of the main issues for literary archival work in Namibia. Participants included Namibian government officials, archivists, librarians, literary and other authors, and workers in the cultural industries. Discussions ranged widely, with great animation and occasional indignation (it is not easy to make a living as a Namibian author), but were constructive and thoughtful and led to a number of definite decisions and ways forward.

The first question to be considered was straightforward but fundamental: if new collections of literary papers are to be established here, should we be thinking in terms of one principal repository or several?

There can sometimes be advantages to being a late starter, in that other models and ways of working are available for consideration. Through the work of the Network and the Section for Archives of Literature and Art of the International Council on Archives (ICA), it was clear that there were a number of non-African models available for Namibia to examine. It would be worth reviewing here some 
of the practices in other countries which provided points of reference for the Windhoek discussions.

\section{International Comparison: Namibia and Brazil}

Brazil had been identified as one of the countries with an outstanding record of collecting literary manuscripts and valuing its literary heritage. Its circumstances were very different from those in Namibia, but its possible use as a best-practice model was of interest. There is a long heritage of Brazilian literary writing, combined with a university system which often works through specialist institutes, several of them literary and artistic in orientation.

Presentations at Network meetings had identified at least fourteen significant Brazilian collecting institutions for literary manuscripts:

- Acervo dos Escritores Mineiros (AEM), UFMG;

- Arquivo da Academia Brasileira de Letras;

- Arquivo da Fundação Casa de Jorge Amado;

- Arquivo do Museu Casa Guimarães Rosa;

- Biblioteca Nacional do Brasil, Rio de Janeiro;

- Casa de Memória Edmundo Cardoso, Santa Maria;

- Casa Guilherme de Almeida;

- Fundação Casa de Rui Barbosa;

- Fundação Cultural Cassiano Ricardo;

- Fundação Darcy Ribeiro;

- Instituto de Estudos Brasileiros (IEB-USP);

- Instituto de Estudos da Linguagem (IEL-Unicamp);

- Instituto de Filosofia e Ciências Humanas (IFCH-Unicamp);

- Instituto Moreira Salles.

It became clear that Brazil has the good fortune to combine several features which contribute to its excellent achievements in collecting literary archives: its literary language (Portuguese) being one of those which is not widely known or studied by the wealthy collecting countries, so that its market is not disrupted or threatened by international competition; also a strong pride in its national literary culture; a good number of collecting institutions, public and private, which, moreover, are disposed to cooperate with each other; a former colonial power which (unlike France or Britain) does not use its language to claim some sort of archival sovereignty over its former colonies (there is no significant lusophone equivalent to the much-debated idea of francophonie); and a good understanding by literary authors and their heirs of the potential importance of literary manuscripts. It may also be a factor that Brazil, despite its deep literary culture, has produced no global literary super-stars, no Nobel Laureates for example. Whatever the balance of these reasons, Brazil presents an example of a country whose literary papers have been much less 
"diasporic" than those of many other countries in the world, especially in postcolonial situations (Sutton, 2016). It was felt to represent a model to which Namibia might aspire at some future time, but a rather distant model for a country in the beginnings of establishing its literary collections.

\section{International Comparison: Namibia and Singapore}

The position in Singapore, one of the world's smallest nations, which had become a "self-governing" British colony in 1955, part of Malaysia in 1963, and then an independent nation in 1965, was closer to Namibia's experience. Singapore had been a British colony since 1819, with partial self-governing status from 1955 to 1963. It had British colonial (and hence archival) traditions, and a multilingual history. In Singapore literary archives are principally divided between the National Library (which has the brief to collect literary and other personal manuscript collections) and the National Archives (which has the brief to collect archival collections of national interest, inevitably including some non-literary collections with literary authors represented in them). This distinction (literary papers in the national library; papers of national interest, sometimes including literary authors, in the National Archives) has been found to be fairly widespread, and provided the first idea to come under serious practical consideration for Namibia.

\section{International Comparison: Namibia and Uruguay}

Like Brazil, Uruguay has a strong literary culture, but its collecting of literary manuscripts has very much been focused on the work of the National Library, known as BIBNA (La Biblioteca Nacional de Uruguay). BIBNA holds the papers of over 140 Uruguayan literary authors, and has published some important ideas for the future relating to the changing nature of literary manuscripts in the digital era and the need for appropriate facilities to make born-digital literary papers available to researchers in years to come. Uruguay was another strong and encouraging precedent for Namibia, and it was strangely pleasing that the active comparison of literary collecting in the two countries was presented as a sub-section of the blog of the International Council on Archives, Section for Archives of Literature and Art (SLA) under the fine internationalist heading of "Uruguay-Namibia." As with the situation in Singapore, the Uruguayan example drew attention to the important balance of roles between the National Library and the National Archives, but the predominance of the National Library in Uruguayan literary collecting was not an exact match to Namibian circumstances.

\section{International Comparison: Namibia and Jamaica}

In other countries the US and UK model was more closely followed, with a leading role in the collecting of literary manuscripts being taken by university special collections departments. A number of the Caribbean nations which achieved their 
independence in the 1960s tended to follow this model, especially the islands where the University of the West Indies had developed a campus and a library-Trinidad and Tobago, Barbados, and Jamaica. It was always understood, however, that the National Archives and the National Library would potentially have roles to play, and, in the case of Jamaica, when the archive of Anthony C. Winkler became available early in 2017, the purchase was made by the National Library of Jamaica rather than the University of the West Indies at Mona. This pluralism of collecting institutions is seen as a sign of heritage strength, but the predominance of university special collections in Jamaica and other Caribbean countries did not provide a model which would be immediately applicable in Namibia.

\section{A Pragmatic Namibian Way Forward}

Namibia, then, had taken the opportunity to look at other models in other parts of the world and to review the different possibilities in respect of national library practices, National Archives practices, and the possible involvement of universities. For non-literary personal papers there had been some collection-building in both the National Archives and the National Library, and there was a need for clearer definitions and for a collecting policy. In the course of the Windhoek meetings, a consensus was agreed which seemed to be right for Namibia and which made sense to archivists and librarians alike. The consensus position for Namibia did not exactly match any of the models studied: it was agreed in 2015 that the National Library of Namibia would cease to collect archives and manuscripts collections and would retain only manuscript items that were directly related to its special collections. Henceforth all archives and manuscripts collections would go to the National Archives and in due course the National Library would also transfer its historical archival collections. The availability of good quality storage space in the National Archives was a significant factor in this decision. The participants at the Windhoek meeting were advised that the diversity of international models made it clear that there was no single best way to ensure the collecting of literary archives in any particular country; what mattered was enthusiasm and commitment and finding a solution that worked. For Namibia that solution was for all literary collections to reside in the National Archives.

\section{Types of Literary Author}

Another factor informing the decision to proceed by collecting literary manuscripts through the National Archives of Namibia was the nature of literary writing and literary writers in the country. Very few writers were exclusively literary authors; writers could not expect to earn their livelihoods exclusively by their poetry, drama, fiction, or screenplays. Some literary authors were therefore also journalists, travel writers, or essayists; several had multiple roles. As with the Sandinista movement in Nicaragua in the 1980s, a number of public figures in Namibia were also literary authors, including government ministers. The SWAPO activist and government 
minister Peya Mushelenga, for example, has also published poetry in the Ovambo language. It is hoped that all of his archival papers, political and literary, will in due course find their way to the National Archives of Namibia as one collection. This sort of combination of public life and literary life can be seen as a further reason to choose the National Archives as the principal repository.

\section{Heritage and National Pride}

International examples both negative and positive were considered in demonstrating that literary manuscripts can form part of the ideas of cultural heritage and patrimony which are so important to new nations. The role of heritage and patrimony in building national pride is easily accepted in Namibia, whose independence struggle against apartheid South Africa always drew on the need to emphasize national identity and pride. As a result, the National Archives of Namibia already had a mission statement which included a commitment to collect manuscripts "deemed to have a national heritage significance" and "representative of national cultural activity."

\section{Working with Namibian Authors}

It had become clear that in countries which had developed strong traditions of collecting literary papers, ways of working with living literary authors were crucially important. In Namibia, the National Archives and the National Library have been regular partners in networks which brought together writers, performers, screenwriters, and artists. These networks, previously used for events and exhibitions in particular, were available for the new discussions about literary archives and were seen as one of the best settings in which to alert authors to the new interest in their archives and correspondence.

\section{What Constitutes a Namibian Literary Manuscript?}

International precedents and comparisons will enable Namibia to reach decisions about which papers to try to collect, and what should be considered a literary manuscript. Notebooks containing early drafts would be considered as collectable and of interest, as would later drafts of poems, novels, essays, scripts, plays, and other literary writings-whether handwritten, typescript, or computer-generated. Correspondence of literary authors would be collected, including emails. Personal and domestic notes could also be of interest to future biographers, and it would not be the job of the present-day archivist to try to judge whether or not future scholars and biographers would be interested in an autograph notebook which listed only places visited, business appointments, or items to be bought at the shops. All notebooks would be collected, retained, and catalogued.

\section{Deciding What to Collect}

The meeting in Windhoek reflected upon the best ways of collecting the most important literary material. It was noted that the major national collector in the UK, 
the British Library, used the principle of pre-eminence in establishing which authors would be considered to be of special national significance. The problem with this approach is that ideas of pre-eminence change over time and the collecting institution may be left with a set of criteria which no longer have general respect and may even attract mockery. ${ }^{1}$ In the case of Namibia it was agreed that there was no need for archivists to attempt value judgements on the merits of any particular author's works. Papers of published Namibian literary authors would be collected when they became available, and the value judgements would be left to literary scholars. From the authors' side, a substantial and strongly felt Namibian issue which was repeatedly stressed during the Windhoek workshops is that while the national liberation struggle is a critical part of national history, it must not be seen as the only important (or collectable) subject of Namibian literature. From the archivists' side, the idea of intervening to preserve archives which would otherwise be at risk of disappearance (as described in the essay by Jens Boel in this volume) was a strong motivation.

\section{Deciding How to Collect}

There are ten or twelve standard ways in which archival institutions acquire literary papers, including private purchase, purchase at auction, purchase from a dealer, bequest, donation, transfer from another institution, government intervention, rescue, long loan, deposit, and acceptance in lieu of tax. In the Namibian context, purchase was unlikely, in normal circumstances, to be an available option. This in itself presented an early problem, as discussion with authors about the importance of their papers inevitably led to queries about monetary value, and raised awareness about authors' expectations in other countries. In particular, the notion that a literary archive could represent the author's pension fund can be found in memoirs and essays by writers in other countries, and some of the prices (or reputed prices) paid by North American and European institutions gave rise to the thought that even a payment of one-tenth that amount in Namibia would be hugely attractive. It has been necessary to calm these ideas by reference to the absence of a significant purchase budget in the National Archives and the absence of an international market in papers of Namibian authors. In general, though, most Namibian authors contacted were receptive to the idea that their archives might find a respected place in their National Archives and that study of their writings might thereby continue into the future. Many of these authors were indeed prepared to consider the preferred acquisition method, which was donation.

\section{Technical Matters: Contracts and Copyrights}

The need for a contract between the National Archives of Namibia and each donor, depositor, or vendor was clear from the beginning, and already had precedents in

I The British Library is occasionally teased for its excessive historically based interest in littleread male writers whose names begin with B-Barrie, Belloc, Binyon, Blunden, Bottomley, Bridges, and so on. 
the acquisition of non-literary personal papers. It was also important to reassure authors that copyright in their manuscripts remained with them and would not transfer to the National Archives unless they specified that they wished to assign their rights. The Copyright and Neighbouring Rights Protection Act of Namibia (1994) establishes a copyright duration of 50 years after the death of the author for both published and unpublished works, so any literary work found in the archives after the author's death would benefit their heirs in the event of publication. Members of the Diasporic Literary Archives Network worked with the staff of the National Archives of Namibia to draw up templates of a draft contract for donation of a literary archive (or a single manuscript) and draft documentation on copyright matters. The documentation included clauses whereby the author or heirs could delegate minor queries and permissions for small amounts of copying to the National Archivist.

\section{Cataloguing, Exhibitions, and Availability to the Public}

It was understood that in most cases authors would welcome the production of exhibitions and displays of their work, but might wish to have a final veto on the inclusion of personally sensitive material. It was also felt to be normal that a depositing author might expect to have their papers catalogued within a reasonable period of time (say, three years). The template documentation included clauses accordingly. The British document Authors and Their Papers: A Guidance Sheet for Authors and Writers, produced by the Diasporic Literary Archives Network and its partners (and reproduced as Appendix 1 below) was found to be generally usefully, although it was agreed that ideally a Namibian version ought to be produced.

\section{Scholarship, Biography, and History}

The ways in which literary papers can be used came under review, but here it was felt that there was no significant difference between Namibia and all other countries with literary interests. Literary papers are used for scholarly study of texts, drafts, and versions, to provide evidence for aspects of the creative process in the study of how poems, novels, plays, stories, life-writings, and other literary works come to be composed. Personal papers and correspondence (including emails) are the fundamental raw materials for biographers and for writers of cultural history, who may study how literary authors interacted with each other, influenced each other, and loved and hated each other in the past.

\section{The Digital Future}

The acquisition of literary papers in digital form can be a daunting prospect for archivists, especially when they are only just beginning to build literary collections. The non-availability of specialist or reconditioned equipment for viewing older digital materials is a serious challenge, and users' expectations and requirements remain largely unknown and untested in respect of digital collections (Chassanoff 
2013; Sutton 2014). If there is uncertainty about users and their willingness to consult digital materials in Europe and even the USA, this is likely to be still more true in countries like Namibia. Members of the Diasporic Literary Archives Network wished to reassure Namibian colleagues that it is perfectly normal to begin collection-building with paper archives and perfectly acceptable to be clear that for, say, the first five years of collection-building, digital materials would not be sought. The way forward for Namibia as regards digital collections would be to continue to participate in international networks and to learn from best practice in other countries, perhaps to sample one or two "hybrid" collections, but not to seek to be a digital pioneer.

\section{Conclusion: A Good Start for Namibia, A Possible Model for Others}

The experience of Namibia and its archivists since 2010 has been very positive in respect of Namibian literature and Namibian literary writers. It has also attracted attention from archivists and authors in other countries in the region. In particular there was felt to be relevance for the countries grouped within the regional branch of the International Council on Archives for eastern and southern Africa (ESARBICA) extending from Namibia as far east and north as Kenya. The ESARBICA conference in Lilongwe, Malawi, therefore added this topic to a plenary session in August 2017, and archival colleagues in Lilongwe expressed their interest in developing collections of private papers (literary and non-literary) following some of the ideas which have emerged from the work in Namibia.

The general principles, themes, ideas, and conclusions, as presented in Lilongwe, can be summarized as follows:

- Namibian archivists will be happy to share their early experiences in working with literary manuscripts with colleagues in other African countries. This will include honest assessments of challenges and difficulties as well as descriptions of successes;

- Countries with pride in their heritage and culture should be collecting the literary archives and correspondence of their principal authors;

- It is more important to reflect wide literary diversity within a country than to try to establish principles of literary pre-eminence;

- Close personal working by archivists with literary authors, their families, and their heirs is a vital part of this type of collection-building;

- There is no single institutional model for the collecting of literary papers in any one country, but there are a wide range of international examples to be examined. In the end, Namibia chose a model which is distinctively its own, based in the National Archives, but each new collecting country would need to consider and decide what would work best within its own existing institutions;

- Collecting policies and definitions should be generous and inclusive. Archivists should not seek to limit the types or genres of material accepted from their 
collected authors. The acquisition of correspondence should be seen as just as important as the acquisition of manuscripts and personal papers, and "related materials" should also be acquired-including photographs, legal papers, passports, prison documents, scribbles, and doodles;

- Working closely with the Diasporic Literary Archives Network was an ideal way to gain access to information about international best practice, typical problems and challenges, objectives, priorities, and financial matters. Both the Namibian archivists and the members of the Diasporic Literary Archives Network would be happy to work in the future with colleagues in other countries, especially countries in sub-Saharan Africa, who are interested in the possibility of starting out on building new literary collections.

\section{Bibliography}

Chapman, Michael. "Making a Literature: The Case of Namibia." English in Africa 22 (October 1995): 19-28.

Chassanoff, Alexandra. "Historians and the Use of Primary Source Materials in the Digital Age." American Archivist 76 (2013): 458-80.

Diasporic Literary Archives Network. www.diasporicarchives.com.

Diasporic Literary Archives Network et al. Authors and Their Papers: A Guidance Sheet for Authors and Writers, 2015. Available online at http://glam-archives. org.uk/?p=1726, and as Appendix 1 of this volume.

Fallon, Helen. "As Honest and Realistic as Possible: The Namibian Writer, Neshani Andreas." Africa 72 (2007): 24-25. http://eprints.maynoothuniversity.ie/965/.

Haaskeen, Petrus. Profiles of a Hero: Poems on the Life and Times of His Excellency Dr Sam Shafiishuna Nujoma, President of the Republic of Namibia. Windhoek: Gamsberg Macmillan, 2000.

International Council on Archives. Section for Archives of Literature and Art (SLA) blog. literaryartisticarchives-ica.org/blog/.

Namibia: Copyright and Neighbouring Rights Protection Act, 1994. World Intellectual Property Organization. www.wipo.int/wipolex/en/text.jsp?file_id=222896.

Nujoma, Sam. Our Struggle Has Never Been Against Individual Minority White Settlers, It Has Been Against a System. Luanda: SWAPO Department of Information and Publicity, 1980.

- Where Others Wavered: My Life in SWAPO and My Participation in the Liberation Struggle of Namibia. London: Panaf Books, 2001.

Sutton, David C. "The Destinies of Literary Manuscripts: Past, Present and Future." Archives and Manuscripts 42 (2014): 295-300.

. "The Diasporic Literary Archives Network and the Commonwealth: Namibia, Nigeria, Trinidad \& Tobago, and Other Examples." New Review of Information Networking 21 (2016): 37-51.

Tell Them of Namibia: Poems from the National Liberation Struggle. Compiled by Simon Zhu Mbako. London: Karia, 1989. 